\title{
Phenotypic Divergences in Growth and Reproduction Underpin The Invasion of Suckermouth-Amored Catfishes to Lotic and Limnic Habitats in Vietnam
}

\author{
Dien Tran Duc ( $\nabla$ mrtran_cnvb@yahoo.com ) \\ Coastal Branch, Vietnam - Russia Tropical Center https://orcid.org/0000-0002-9512-1336 \\ Vo Thi Ha \\ Vietnam - Russia Tropical Center \\ Mai Dang \\ Institute of Veterinary Research and Developmeny of Central Vietnam \\ Huynh Minh Sang \\ Nhatrang Oceanography Institute: Institute of Oceanography Nha Trang \\ Khuong V. Dinh \\ Nhatrang University \\ Nguyen Trinh Duc Hieu \\ Nhatrang Oceanography Institute: Institute of Oceanography Nha Trang \\ Stolbunov I.A \\ Russian Academy of Sciences
}

\section{Research Article}

Keywords: Pterygoplichthys spp., growth, reproduction, invasive fish, freshwater ecosystem, Vietnam

Posted Date: March 7th, 2022

DOl: https://doi.org/10.21203/rs.3.rs-1346356/v1

License: (c) (i) This work is licensed under a Creative Commons Attribution 4.0 International License. Read Full License 


\section{Abstract}

Suckermouth-amored catfishes (Pterygoplichthys spp.) is one of the most widespread invasive species in Vietnam. However, it is relatively unknown how these species have evolved in divergent adaptations to local conditions varying in habitat types, which is essential for managing their invasion in Vietnam. We addressed this by analyzing a large number of fish (766 phenotypes) collected in lotic (Dinh River) and limnic (Suoi Trau Resevoir) habitats in southern Vietnam during one year. Allometric growth patterns estimated by von Bertalanffy growth functions were $L_{t}=500\left(1-e^{-0.71(t-0.44)}\right)$ in Dinh River and $L_{t}=346\left(1-e^{-1.01(t-0.62)}\right)$ in Suoi Trau Resevoir. Estimated fish age was 2.9 to 4.2 years old. The percentage of fish with matured ovaries peaked in August (100\%) and was lowest in February ( $<10 \%)$, indicating that these fish breed all year round. The main reproductive season is April-October, with a peak in July-August as indicated by gonadosomatic indices index and monthly changes in the percentage of matured fish. The length at 50\% maturity 22.93 and 17.51 $\mathrm{cm}$ for females from lotic and limnic habitats, respectively. Lotic fish had the fecundity (5830 \pm 546 oocytes/ind.) which was five times larger than that of limnic fish (1042 \pm 107 oocytes/ind.). This result was consistent with the larger oocytes of females: $2.94 \pm 0.03$ and $2.58 \pm 0.01 \mathrm{~mm}$ for fish from Dinh River and Suoi Trau Resevoir, respectively. The faster growth and bigger fish with higher fecundity in the lotic habitats suggest they can accelerate greater population growth, potentially affecting local communities more than those from limnic habitats. Our study sheds light on substantial phenotypic divergences in reproduction and growth of the armored catfish between lotic and limnetic habitats in Vietnam, which is fundament for arriving at an effective management plan.

\section{Introduction}

Invasive species have recently been identified as one of five important drivers pushing $~ 1$ million species to the brink of extinction (IPBES 2019). Thousand species have been moved from their native habitats, both accidental and intended purposes with human activities, and become invasive species in other regions (Burgiel and Muir 2010). Invasive species have caused serious consequences to the environment such as altering the abundance, diversity of local communities, the function and ecological services of invaded habitats (Schofield and Loftus 2014; Torchin and Mitchell 2004). The invasions represent one of the most serious threats to freshwater biodiversity presently (Reid et al. 2019). For example, the invastion of Pterygoplichthys pardalis species in India, the Philippines has reported to cause huge damage to the native species diversity (Bijukumar et al. 2015; Orfinger and Goodding 2018). Among others, armored catfish, genus Pterygoplichthys, originated from South America have invaded freshwater water habitats in 21 countries from Asia, Europe, Africa to North America (Orfinger and Goodding 2018). Pterygoplichthys spp. have a long digestive track (up to $6 \mathrm{~m}$, mean = $2.7 \mathrm{~m}$ ), a broad food spectrum, fast growth rate and high tolerance to environmental conditions, outcompeting native species for food and habitats (Mendoza et al. 2009; Suresh et al. 2019; Stolbunov and Tran Duc Dien 2019; Stolbunov, Gusakov et al. 2021), change the composition, structure, fish production cutback and function of local freshwater communities (Gusakov et al. 2018; Stolbunov and Dien 2019; Hussan et al. 2019; Stolbunov et al. 2020; Stolbunov, Tran Duc Dien et al. 2021). Armored catfish has been considered as a severe threat to freshwater fisheries in Eurasia, United States of America (Nico 2009; Hossain et al. 2018) and Mexico (Alfaro et al. 2009; Mendoza et al. 2015).

In Vietnam, Pterygoplichthys spp. firstly appeared in Dong Nai River system and Tri An Reservoir in 2000 (Stolbunov et al. 2021) and spread quickly to the freshwater bodies in Vietnam. Currently, Pterygoplichthys spp. present in all main River Basins and Reservoirs in southern Vietnam (Gusakov et al. 2018; Stolbunov and Dien 2019; Stolbunov et al. 2020, Stolbunov et al. 2021). Given these species are thriving in freshwater habitats in Vietnam, it is supposed that they have evolved in locally divergent adaptations by changes in morphology, diets, growth, development and reproduction; key characterisitics for the successful invations (Stolbunov et al. 2021). A few studies have documented some useful, but highly discreted information on the reproduction of this species in Vietnam. The reproductive biology of Pterygoplichthys spp. was first examined in Dinh River from 2010 to 2012 with only 34 individuals ( 5 females) in October-December, 2010 and 10 individuals (6 females) in January 2012 (Zworykin and Budaev 2013). The catfishes can spawned from October to January and maturity 
stage included different sizes oocytes (1-3 mm in diameter). These results did not allow us to overview the reproductive cycle of Pterygoplichthys spp. and how they have evolved in different growth and reproductive strategies in various habitats. The data obtained through morphological and molecular-genetic analyzes, as well as the assessment of the color patterns of fish, have shown that the Vietnamese reservoirs and rivers are inhabited by armored catfishes of two species:

Pterygoplichthys pardalis (Castelnau, 1855) and P. disjunctivus (Weber, 1991), as well as an interspecific hybrid P. pardalis $\times$ $P$. disjunctivus (Stolbunov el al. 2021), further challenging the effort for conservation and management of freshwater habitats in Vietnam.

In this study, we investigated the growth and reproductive biology of Pterygoplichthys spp. in lotic and limnic habitats in southern Vietnam for one year. We determined the length-weight relationship and growth parameters, male-female distinction, sex ratio, gonadal development stages, spawning season, size at the first sexual maturity, fecundity and oocyte diameter. By comparing these characteristics of fish in different habitats we highlighted phenotypic divergences of Pterygoplichthys spp.. Our results provide an important scientific base for management, and further to control the spread of this invasive fish in Vietnam.

\section{Materials And Methods}

\subsection{Sampling populations}

A total of 389 females and 377 males were collected from Dinh River ( $12^{\circ} 29.740^{\prime} \mathrm{N}, 109^{\circ} 7.686^{\prime} \mathrm{E}-\mathrm{a}$ lotic habitat) and Suoi Trau Reservoir (12 $30.302^{\prime} \mathrm{N}, 109^{\circ} 2.694^{\prime} \mathrm{E}$ - a limnic habitat) in southern Vietnam from March 2019 to February 2020 (Fig. 1). Location, hydrological measurements and some water quality parametters of sampling stations are presented in Fig. 1 and Table. 1. Temperature and rainfall data were collected from a meteorology station in Ninh Hoa from January 2019 to January 2020 (Fig. 2). Briefly, the temperature varied between $25.2-31.4^{\circ} \mathrm{C}$ (higher from April to October) and the monthly average rainfall was 0-271.7 $\mathrm{mm}$ (higher from September to November).

\subsection{Sample processing and data collection}

The fish were transported to the laboratory at the Russia Tropical Center, Nha Trang city, Khanh Hoa provice, Vietnam. Fish were identified to the genus based on the descriptions by Armbruster and Page (2006). Total length $\left(L_{t}\right)$ and standard length $\left(L_{s}\right)$ were measured to the nearest $0.1 \mathrm{~mm}$, total weight $\left(\mathrm{W}_{t}\right)$ and weight without internal organs $\left(\mathrm{W}_{\text {wi }}\right)$ were recorded to the nearest $0.1 \mathrm{~g}$ using a precision balance SHUN DA Digital Scale SD03-KS. Gonad weight $\left(\mathrm{W}_{\mathrm{g}}\right)$ was recorded to the nearest 0.01 g using a precision balance Electronic Precision Balance (KD-TBED-3000) and 0.0001g using an Electronic Balance AX 200, No D 422800034.

Ovary development stages of fishes were determined using methods described by Nikolsky (1963) and King (1995), using a microscope (Olympus, CKX53SF) at $10 \mathrm{X}$ and $4 \mathrm{X}$ magnifications. Ovary development stages were recognized macroscopically based on the external morphology of the ovary and microscopically based on the sex cell structure.

Ovary of each gonadal development stage was dissected and fixed in $10 \%$ neutral formaldehyde solution for at least 24-48 $\mathrm{h}$ for histology. After dehydrating by passing the tissue through a series of alcohol solutions of $70,85,95$ and $100 \%$, the samples were embedded in paraffin. The histological sections $(5-7 \mu \mathrm{m})$ were stained with hematoxylin and eosin (H\&E) for microscopic examination. The samples were photographically analyzed and documented using a microscope (Olympus, CKX53SF) after the scale was calibrated.

The spawning season was identified as period with more than $50 \%$ fish having ovaries at stages III, IV and V and greater GSI were observed (Sang and Lam 2018). A total of 30 ovaries at stages IV and V was used to estimate fecundity. Ovaries were divided into small portions and fixed in formalin $(\sim 1 \%)$, and weighed $\left(\mathrm{W}_{\mathrm{sp}}\right)$. Subsequently, all oocytes in each portion were 
transferred to a counting chamber and counted number of yolked oocytes $\left(\mathrm{O}_{\text {yolked }}\right)$ and number of all oocytes $\left(\mathrm{O}_{t}\right)$ using naked eyes.

Diameters of these Top Decile oocytes in breeding season (Gibbs et al. 2008; Gibbs et al. 2017) were measured using Measure Arbitrary-line functions of the LCmicro software (Product Version 2.1, Core Version XV 3.15, Package number 5180, the copyright year 2016) after the scale was calibrated. Images of these oocytes were captured at $4 \mathrm{X}$ magnification using a microscope (Model CKX53SF) connected with a digital camera (Olympus LC30, Olympus, U-T0.5XC-3, SN 7B02181).

\subsection{Data analyses}

Length distribution and length-weight relationship (Dong et al. 2019)

The relationship between total length and total weight was calculated for each site using power regression equation:

$$
W=a L^{b} e^{\epsilon}, \epsilon \tilde{N}\left(0, \sigma^{2}\right)
$$

Where:

a is the intercept of the regression or shape coefficient

$b$ is the allometric or slope parameter (Ricker 1975).

The optimal regression parameters were gained by minimizing the residuals errors using the ordinary least square method (O'Brien 2012). Student's t-test was utilized to test whether the slope of regression was significantly different from 3 ,

indicating the growth pattern of fish: isometric ( $b=3$, no change of density and shape as one fish grows), positive allometric ( $b>3$, the fish becomes relatively stouter or deeper-bodies as it becomes longer) or negative allometric ( $b<3$, fish becomes slimmer as it grows) (Ye et al. 2007). Generally, the allometric coefficient (b) is within the range from 2 to 4 for most fish species (Koutrakis and Tsikliras 2003), and thus this thumb rule can be used to corroborate the validation of the length and weight relationships of Pterygoplichthys spp. in our study. All statistical analyses were performed using R software version 3.3.2 (R Core Team 2017) with a significance level (a) equal to 0.05 .

The von Bertalanffy growth model (VBGM) was used to describe the growth of Pterygoplichthys spp. (Von Bertalanffy 1938):

$$
L_{t}=L_{\infty}\left(1-e^{-K\left(t-t_{0}\right)}\right)
$$

where $L_{t}$ was the expected or average $L$ at time (or age) $t, L_{\infty}$ is the mean asymptotic $L, \mathrm{~K}$ is growth coefficient, expressing the rate $\left(\right.$ year $^{-1}$ ) at which the $L_{\infty}$ is approached and $t_{0}$ is the hypothetical age at which fish $L$ equals zero. While VBGM parameters can be estimated by length (weight)-age approach, the length-based method is most extensively adopted, especially in tropical and subtropical regions (Sparre and Venema 1998). In this study, length-frequency datasets with a constant class size $(30 \mathrm{~mm})$ were used to obtain the optimal growth parameters (corresponding to the maximum of the goodness of fit index, Rn) using the R software (ELEFAN functions in TropFishR package), (Gayanilo, Sparre and Pauly 2005). The theoretical age $\left(t_{0}\right)$ was determined by the empirical equation of Pauly (1983):

$$
\log _{10}\left(-t_{0}\right)=-0.392-0.275 \log _{10}\left(L_{\infty}\right)-\log _{10}(K)
$$

In order to compare the growth performance of different geographical populations, the growth performance index (GPI) $f^{\prime}$ (phi-prime) was calculated using the following formula (Pauly and Munro 1984):

$$
\emptyset^{\prime \prime}=\log _{10}(K)+2 \log _{10}\left(L_{\infty}\right)
$$


The potential or expected longevity $\left(t_{\max }\right)$ of Pterygoplichthys spp. was calculated based on Pauly's (1983) empirical equation:

$$
t_{\max }=\frac{3}{K}
$$

where $\mathrm{t}_{\max }$ is the approximate maximum age of Pterygoplichthys spp. at each study site, and $K$ is the growth constant in von Bertalanffy growth function.

Gonado-somatic index (GSI) was calculated using the formula (Samat el al. 2016):

$\operatorname{GSI}(\%)=100 \times \mathrm{W}_{\mathrm{g}} / \mathrm{W}_{\mathrm{wi}}$

The absolute first batch fecundity $\left(F_{b}\right)$ was estimated using the following formula (Gibbs et al. 2008; Gibbs et al. 2017): $F_{b}$ (oocytes/ind. $)=\left(\mathrm{W}_{\mathrm{g}} / \mathrm{W}_{\mathrm{sp}}\right) \times \mathrm{O}_{\text {yolked }}$

The absolute total fecundity $\left(F_{t}\right)$ was estimated using the following formula (Rueda-Jasso et al. 2013): $F_{t}$ (oocytes/ind.) = $\left(\mathrm{W}_{\mathrm{g}} / \mathrm{W}_{\mathrm{sp}}\right) \times \mathrm{O}_{\mathrm{t}}$

Relative first batch fecundity $\left(\mathrm{RF}_{\mathrm{b}}\right)$ was calculated using the following formula (Gibbs et al. 2008; Gibbs et al. 2017): $R F_{b}$ (oocytes $/ g$ ) $=F_{b} / W_{\text {wi }}$

Relative total fecundity $\left(\mathrm{RF}_{t}\right)$ was calculated using the following formula 5 (Rueda-Jasso et al. 2013): $R F_{t}$ (oocytes/g) = $\mathrm{F}_{\mathrm{t}} / \mathrm{W}_{\mathrm{wi}}$

To describe the reproductive strategy of catfishes, we developed an index of prediction of number of spawns that was calculated as $F_{b} / F_{t}(\%)=F_{b} / F_{t} \times 100$. If index $F_{b} / F_{t}=100 \%$ showed the catfish is single spawner; If index $F_{b} / F_{t}<100 \%$ showed the catfish is a multiple spawner.

The relationship between total fecundity and total weight was statically determined using the following formula: $F_{t}=a W_{t}+b$ where $a$ and $b$ are constant values obtained from linear model function in RStudio (Duarte and Araújo 2002). Similarly, the relationship between fecundity and total length is statically determined using the following formula: $\log \left(F_{t}\right)=a L o g\left(L_{t}\right)+b$ where $a$ and $b$ are constant values obtained from linear model function in RStudio (Sang and Lam 2018).

The fish were considered matured when ovaries were at stage III to V (King 1995). The size at first sexual maturity of female sucker-mouth catfish was estimated using a logistic regression of the form was first fitted to the proportion of mature females to estimate size at maturity (McLeay et al. 2019).

$y=1 /(1+\exp -(a+b * x)$ Eq. 1

in which $y$ is the probability of an individual being mature at determinate

$\mathrm{x}$ (total length, $\mathrm{mm}$ )

a (intercept) and

b (slope) are estimated parameters.

Size at the first sexual maturity $\left(L_{50}\right)$ was calculated as the average total length at which $50 \%$ of females matured for each of habitats (Dinh River and Suoi Trau Reservoir) as:

$L_{50}=-a / b$ Eq. 2 
Confidence intervals (2.5\% and $97.5 \%)$ for estimates of size at maturity were then derived via bootstrapping procedures within SizeMat (N iterations = 1000) (McLeay el al. 2019). All analyses were done using the SizeMat package (version 0.2.0) within R statistical software (v 3.3.2, R Development Core Team, R Foundation for Statistical Computing) (McLeay et al. 2019).

Sex ratio was determined by the ratio of male and female numbers. Chi-square test ( $R$ statistical software) was used to test the difference between the number of males and females in the natural population of the fish. $p<0.05$ was considered as statistically significant.

\section{Results}

\subsection{Length-frequency distribution and age structure}

There was a wide range in the total length of Pterygoplichthys spp. in both Dinh River $(L=177-454$, mean $=315.70 \mathrm{~mm}$ for females; and 166-479, mean = $329.62 \mathrm{~mm}$ for males) and Suoi Trau Reservoir $(\mathrm{L}=82-313 \mathrm{~mm}$, mean = $201.21 \mathrm{~mm}$ for females; and 88-316 mm, mean $=211.85 \mathrm{~mm}$ for males, Fig. 3 and Table 2). There was a statistical difference in the mean total length of females and males and of fish between two habitats (all $p$ values $<0.01$, Kruskal-Wallis). Within each habitat, the difference between the total length of females and males was small; females were about $\sim 5 \%$ smaller than males, which was consistent in both habitats. However, the difference in the total length of fish between habitat was pronounced; both females and males from Dinh River were about 1.5 times longer than those from Suoi Trau Reservoir $(p<0.01)($ Fig. 4 and Table 2). The estimated maximum age of fish was 4.2 and 2.9 years for fish from Dinh River and Suoi Trau Reservoir, respectively. 
Table 2

Length-Weight relationship of the Pterygoplichthys spp. collected throughout the whole year based on the equation $W=a L^{b} e^{\epsilon}, \epsilon \tilde{N}\left(0, \sigma^{2}\right)$ (a: intercept and $b$ : slope of the equation). Minimum (min) and Maximum (max) of Length, Weight;

$\mathrm{Cl}(b)$ : confidence intervals of $b ; \mathrm{R}^{2}$ : correlation coefficient of the regression, $\mathrm{p}$ is significance of regression with all $\mathrm{p}$ being significant at $<0.05$, t-test significance is conducted to verify if $b$ is significantly different from consensus $b=3$

\begin{tabular}{|c|c|c|c|c|c|c|c|c|c|c|}
\hline \multirow[t]{2}{*}{ Stations } & \multirow[t]{2}{*}{ Sex } & $\begin{array}{l}\mathrm{L}_{\min }^{-} \\
\mathrm{L}_{\max } \\
(\mathrm{mm})\end{array}$ & $\begin{array}{l}W_{\min }^{-} \\
W_{\max } \\
(g)\end{array}$ & $a$ & $b$ & $\mathrm{Cl}(b)$ & $\mathrm{R}^{2}$ & $\begin{array}{l}\mathrm{p} \text { of } \\
\text { regression }\end{array}$ & t-test sig & \multirow[t]{2}{*}{$\begin{array}{l}\text { Growth } \\
\text { behavior }\end{array}$} \\
\hline & & $\begin{array}{r}\text { (Mean } \\
\pm \text { SE) }\end{array}$ & $\begin{array}{r}\text { (Mean } \\
\pm \text { SE) }\end{array}$ & & & & & & & \\
\hline \multirow{4}{*}{$\begin{array}{l}\text { Dinh } \\
\text { River }\end{array}$} & Females & \multirow{2}{*}{$\begin{array}{l}177- \\
454 \\
(315.70 \\
\pm \\
62.90)\end{array}$} & $44-943$ & \multirow[t]{2}{*}{0.000015} & \multirow[t]{2}{*}{2.89} & \multirow{2}{*}{$\begin{array}{l}2.79- \\
2.98\end{array}$} & \multirow[t]{2}{*}{0.94} & \multirow{2}{*}{$\begin{array}{l}<2.2 \times 10^{-} \\
16\end{array}$} & \multirow[t]{2}{*}{0.02} & \multirow{2}{*}{$\begin{array}{l}\text { Negative } \\
\text { allometry }\end{array}$} \\
\hline & $\begin{array}{l}(n= \\
230)\end{array}$ & & $\begin{array}{l}(286.13 \\
\pm \\
179.27)\end{array}$ & & & & & & & \\
\hline & \multirow{2}{*}{$\begin{array}{l}\text { Males } \\
(n= \\
222)\end{array}$} & \multirow{2}{*}{$\begin{array}{l}166- \\
479 \\
(329.62 \\
\pm \\
63.34)\end{array}$} & $46-767$ & \multirow[t]{2}{*}{0.000044} & \multirow[t]{2}{*}{2.69} & \multirow{2}{*}{$\begin{array}{l}2.60- \\
2.77\end{array}$} & \multirow[t]{2}{*}{0.94} & \multirow{2}{*}{$\begin{array}{l}<2.2 \times 10^{-} \\
16\end{array}$} & \multirow{2}{*}{$\begin{array}{l}< \\
1.5 \times 10^{-}\end{array}$} & \multirow{2}{*}{$\begin{array}{l}\text { Negative } \\
\text { allometry }\end{array}$} \\
\hline & & & $\begin{array}{l}(284.40 \\
\pm \\
154.42)\end{array}$ & & & & & & & \\
\hline \multirow{4}{*}{$\begin{array}{l}\text { Suoi } \\
\text { Trau } \\
\text { Reservior }\end{array}$} & \multirow{2}{*}{$\begin{array}{l}\text { Females } \\
(n= \\
157)\end{array}$} & \multirow{2}{*}{$\begin{array}{l}82-313 \\
(201.21 \\
\pm \\
36.50)\end{array}$} & $\begin{array}{l}4.6- \\
245\end{array}$ & \multirow[t]{2}{*}{0.000039} & \multirow[t]{2}{*}{2.69} & \multirow[t]{2}{*}{$\begin{array}{l}2.58- \\
2.80\end{array}$} & \multirow[t]{2}{*}{0.94} & \multirow{2}{*}{$\begin{array}{l}<2.2 \times 10^{-} \\
16\end{array}$} & \multirow{2}{*}{$\begin{array}{l}1.24 \times 10^{-} \\
7\end{array}$} & \multirow{2}{*}{$\begin{array}{l}\text { Negative } \\
\text { allometry }\end{array}$} \\
\hline & & & $\begin{array}{l}(67.32 \\
\pm \\
32.03)\end{array}$ & & & & & & & \\
\hline & \multirow{2}{*}{$\begin{array}{l}\text { Males } \\
(n= \\
149)\end{array}$} & \multirow{2}{*}{$\begin{array}{l}88-316 \\
(211.85 \\
\pm \\
35.42)\end{array}$} & $5.62-$ & \multirow[t]{2}{*}{0.000034} & \multirow[t]{2}{*}{2.66} & \multirow{2}{*}{$\begin{array}{l}2.58- \\
2.83\end{array}$} & \multirow[t]{2}{*}{0.93} & \multirow{2}{*}{$\begin{array}{l}<2.2 \times 10^{-} \\
16\end{array}$} & \multirow{2}{*}{$\begin{array}{l}< \\
3.2 \times 10^{-6}\end{array}$} & Negative \\
\hline & & & $\begin{array}{l}(71.32 \\
\pm \\
31.37)\end{array}$ & & & & & & & allometry \\
\hline
\end{tabular}

\subsection{The length-weight relationships and growth pattern}

Length-weight relationships were illustrated in Fig. 5 and Table 2:

Males in Dinh River: $\mathrm{W}=0.0000443 \mathrm{~L}^{2.69}, R^{2}=0.94, \mathrm{n}=222, p \sim 0$.

Females in Dinh River: $\mathrm{W}=0.0000155 \mathrm{~L}^{2.89}, R^{2}=0.94, \mathrm{n}=230, p \sim 0$.

Males in Suoi Trau Reservoir: $\mathrm{W}=0.0000343 \mathrm{~L}^{2.70}, R^{2}=0.93, \mathrm{n}=149, p \sim 0$.

Females in Suoi Trau Reservoir: $\mathrm{W}=0.0000393 \mathrm{~L}^{2.69}, R^{2}=0.94, \mathrm{n}=157, p \sim 0$.

All males and females had the slope coefficients ( $b$ values) smaller than 3 regardless of the habitats (in Dinh River: $t=-2.27$, $d f=228, p=0.02$ for females; and $t=-7.1, d f=221, p=1.5 \times 10^{-11}$ for males; and in Suoi Trau Reservoir, $t=-5.54, d f=156$, $p=1.2 \times 10^{-7}$ for females; $t=-4,74, d f=148, p=4.9 \times 10^{-6}$ for males), indicating an negative allometric growth pattern for all individuals from sampling populations (Table 2).

Growth parameters 
At Dinh River, fish had $L_{\infty}=500 \mathrm{~mm}, K=0.71, t_{0}=0.44, \emptyset^{\prime}=5.23, R_{\mathrm{n}}=0.29$. For those from Suoi Trau Reservoir, they had $L_{\infty}$ $=346 \mathrm{~mm}, \mathrm{~K}=1.01, t_{0}=0.62, \emptyset^{\prime}=5.08, \mathrm{R}_{\mathrm{n}}=0.498$.

\subsection{Male-female distinction and sex ratio}

Morphology analysis of gonad of these fish indicated that the sex of small fish ( $8.2 \mathrm{~cm}$ in length, $4.1 \mathrm{~g}$ in weight) could be determined using naked eyes. In both habitats, the ratio of armored catfish males and females was 1:1.03.

\subsection{Gonadal stages}

Six maturity stages, including resting phase (I), developing phase (II), ripening phase (III), mature (IV), spawning phase (V) and recovering phase $(\mathrm{VI})$ were identified based on the shape, size, color of the ovaries and histological features (Table 3 , Fig. 6). Key histological features of ovaries of armored catfishes in Khanh Hoa province are presented in Fig. 6. Resting phase: the ovaries are pale pink to translucent in color with ovarian wall was very thin, oocytes are mainly primary growth (PG) types. Developing phase: no oocyte was visible with naked eyes, oocytes grew with nucleus up to $50 \%$ of the whole oocyte area. Ripening phase: Oocytes can be seen by naked eyes, oocytes was pale pink in colour in H\&E stained sections. Mature phase: The ovaries turned to deep yellow color (straw yellow or red-yellow), the oocytes were dark purple in color in H\&E stained sections. Spawning phase: Oocytes are separate and come out if being pressed lightly on the abdomen. Recovering phase: Ovarian wall was more thicker, ovaries are empty or left a few small eggs.

Table 3

Maturity stages of female Pterygoplichthys spp.

\begin{tabular}{|c|c|c|}
\hline \multicolumn{2}{|c|}{ Maturity stages } & \multirow{2}{*}{$\begin{array}{l}\text { Characteristics of ovaries } \\
\text { The ovaries were pale pink to translucent in color with inconspicuous vascularisation. Ovarian wall } \\
\text { was very thin and no oocyte was visible with naked eyes. } W_{\text {gonad }}=0.0164 \pm 0.0058 \mathrm{~g} \text { (range: } 0.0103- \\
0.0280 \mathrm{~g}) . \text { Histologically, oocytes, mainly PG types, were dense and closely distributed. (Fig. } 6 \mathrm{a} \text {; } \\
\text { Fig. } 6 \mathrm{~b}) \text {. }\end{array}$} \\
\hline I & $\begin{array}{l}\text { Resting } \\
\text { phase } \\
\text { (immature) }\end{array}$ & \\
\hline II & $\begin{array}{l}\text { Developing } \\
\text { phase }\end{array}$ & $\begin{array}{l}\text { Ovaries are light yellowish to opaque in color. Vascular supply increased and the blood capillaries } \\
\text { became conspicuous. Oocyte was not visible through ovarian wall with naked eyes. } W_{\text {gonad }}=0.4512 \\
\pm 0.0401 \mathrm{~g} \text { (range: } 0.0204-2.23 \mathrm{~g} \text { ). In histological sections, oocytes grew with nucleus up to } 50 \% \text { of } \\
\text { the whole oocyte area and limited vacuolation (Fig. 6c; Fig. 6d). }\end{array}$ \\
\hline III & $\begin{array}{l}\text { Ripening } \\
\text { phase }\end{array}$ & $\begin{array}{l}\text { Ovaries increased in weight and volume, and were in light color. Oocytes (including stage II and III } \\
\text { oocytes) can be seen by naked eyes. Oocytes increased considerably in size and was pale pink in } \\
\text { colour in H\&E stained sections (Fig. 6e; Fig. 6f). }\end{array}$ \\
\hline IV & Mature & $\begin{array}{l}\text { At close to spawning, the ovaries turned to deep yellow color (straw yellow or red-yellow). The blood } \\
\text { supply increases considerably with a large blood vessel visible along the ovary. Oocytes reached } \\
\text { maximum in size and contained dense yolk particles. In H\&E stained sections, the oocytes were dark } \\
\text { purple in color (Fig. 6g; Fig. 6h) }\end{array}$ \\
\hline V & $\begin{array}{l}\text { Spawning } \\
\text { phase }\end{array}$ & $\begin{array}{l}\text { The ovaries were involved in reproduction. Ripened eggs were released directly into the abdominal } \\
\text { cavity. Oocytes were separate and come out if being pressed lightly on the abdomen (Fig. 6i). }\end{array}$ \\
\hline $\mathrm{VI}$ & $\begin{array}{l}\text { Recovering } \\
\text { phase } \\
\text { (spent) }\end{array}$ & $\begin{array}{l}\text { Ovaries appeared bruised; purple to dark pink in color. Ovarian wall was more thicker, ovaries are } \\
\text { empty or left a few small eggs (Fig. } 6 \mathrm{k} \text { ). }\end{array}$ \\
\hline
\end{tabular}

\subsection{Spawning season}

\section{Monthly changes in the percentage of matured fish}

The matured fish presented all year round, but with a higher percentage during April-October compared to November-March. The percentage of fish with matured ovaries peaked in August (100\%) and lowest in February (<10\%) (Fig. 7a). 
The highest GSIs were $14.94 \pm 1.28 \%$ in fish from Dinh River and $8.48 \pm 1.12 \%$ in fish from Suoi Trau Reservoir, all in August. The lowest GSI was in February $(0.44 \pm 0.06 \%)$ for fish from Dinh river and $(0.04 \pm 0.03 \%)$ for fish from Suoi Trau in April (Fig. 7b).

\subsection{Length at first sexual maturity (50\% maturity)}

The total length at 50\% maturity of females was $175.1 \mathrm{~mm}(\sim 130 \mathrm{~mm} \mathrm{~L})$ for fish from Suoi Trau Reservoir and $229.3 \mathrm{~mm}$ $\left(\sim 159.1 \mathrm{~mm} \mathrm{~L}_{\mathrm{s}}\right.$ ) for fish from Dinh River (Fig. 8). The smallest matured fish was observed in Suoi Trau with a $\mathrm{L}_{t}$ of $167 \mathrm{~mm}$ and a body weight of $40 \mathrm{~g}$.

\subsection{Fecundity}

The absolute first batch fecundity of the Pterygoplichthys spp. in Dinh River and Suoi Trau Reservoir was $4715 \pm 442$ oocytes/ind. (ranged from 103 to 10083 oocytes/ind.) and $887 \pm 98$ oocytes/ind. (ranged from 150 to 2200 oocytes/ind.), respectively. The relative first batch fecundity of the Pterygoplichthys spp. in Dinh River and Suoi Trau reservoir was $12.37 \pm$ 0.82 oocytes/g (ranged from 0.69 to 21.32 oocytes $/ g$ ) and $13.01 \pm 1.18$ oocytes/g (ranged from 3.26 to 25.23 oocytes $/ \mathrm{g}$ ), respectively. The difference in the absolute first batch fecundity was no longer present when the fecundity was normalized for the body weight. Specifically, the relative fecundity of the fish was not statistically different between two habitats ( $p>$ 0.05) (Table 4).

Table 4

Reproductive parameters of Pterygoplichthys spp from Dinh River $(\mathrm{n}=33)$ and Suoi Trau Reservoir $(\mathrm{n}=31)$.

\begin{tabular}{|c|c|c|c|c|}
\hline Parameters & Unit & $\begin{array}{l}\text { Dinh River } \\
\text { Mean } \pm S E(\min -\max )\end{array}$ & $\begin{array}{l}\text { Suoi Trau Reservoir } \\
\text { Mean } \pm \text { SE (min - max) }\end{array}$ & $p$ \\
\hline $\mathrm{F}_{\mathrm{b}}$ & oocytes/ind. & $\begin{array}{l}4715.33 \pm 441.75(103- \\
10083)\end{array}$ & $886.82 \pm 97.54(150-2000)$ & $<0.05$ \\
\hline$F_{t}$ & oocytes/ind. & $\begin{array}{l}5829.68 \pm 546.08(1143- \\
11010)\end{array}$ & $\begin{array}{l}1042.04 \pm 106.77(150- \\
2255)\end{array}$ & $<.05$ \\
\hline $\mathrm{F}_{\mathrm{b}} / \mathrm{F}_{\mathrm{t}}$ & $\%$ & $81.30 \pm 2.27(7.90-100)$ & $84.09 \pm 2.01(59.26-100)$ & \\
\hline $\mathrm{RF}_{\mathrm{b}}$ & oocytes/g & $12.37 \pm 0.82(0.69-21.32)$ & $13.01 \pm 1.18(3.26-25.23)$ & \\
\hline $\mathrm{RF}_{\mathrm{t}}$ & oocytes/g & $15.19 \pm 0.93(5.75-26.00)$ & $15.51 \pm 1.34(3.26-28.55)$ & \\
\hline $\begin{array}{l}\text { Diameter Top Decile of } \\
\text { oocytes }\end{array}$ & $\mathrm{mm}$ & $2.94 \pm 0.03(2.50-3.46)$ & $2.58 \pm 0.01(2.42-2.80)$ & $<0.05$ \\
\hline $\begin{array}{l}\text { Note: } F_{b} \text { - first batch fe } \\
\text { SE - Standard Error; Mi }\end{array}$ & $t-$ Total fecu & $\begin{array}{l}\text { ity; } \mathrm{RF}_{\mathrm{b}}-\text { Relative first bat } \\
\text { Im (max); ind. - individual }\end{array}$ & ndity; $\mathrm{RF}_{\mathrm{t}}$ - Relative Total Fe & dity; \\
\hline
\end{tabular}

The absolute total fecundity in Dinh River and Suoi Trau Reservoir were $5830 \pm 546$ oocytes/ind. (ranged from 1143 to 11010 oocytes/ind.) and $1042 \pm 107$ oocytes/ind. (ranged from 150 to 2255 oocytes/ind.), respectively. The relative fecundity in Dinh River and Suoi Trau reservoir was $15.19 \pm 0.93$ oocytes/g (ranged from 5.75 to 26.00 oocytes/g) and $15.51 \pm 1.34$ oocytes/g (ranged from 3.26 to 28.55 oocytes $/ g$ ). There was no difference in the mean relative fecundity of the fish among different sampling sites $(p>0.05)$ (Table 4).

The index of $F_{b} / F_{t}$ was $81.30 \pm 2.27 \%$ (ranged from 7.90 to $100 \%$ ) and $84.09 \pm 2.01 \%$ (ranged from 59.26 to $100 \%$ ) for fish from Dinh River and Suoi Trau Reservoir, respectively.

The fecundity was positively correlated with body weight and good explain $\left(F_{t}=16.913 W_{t}-417.847 ; R^{2}=0.721 ; t=8.594 ; p\right.$ $<0.001 ; n=33$ ) and directly proportional to body weight for fishes in Dinh River (Fig. 9a). Only with the $R^{2}$ value (0.417), it is possible to explain this correlation in Suoi Trau Reservoir $\left(F_{t}=31.008 W_{t}-916.922 ; t=4.475 ; p<0.001 ; n=30\right)(F i g .9 b)$. 
Similarly, the fecundity was positively correlated with total length $\left(\log \left(F_{t}\right)=3.7188 \log \left(L_{t}\right)-13.4851 ; R^{2}=0.7964 ; t=11.013\right.$; $p<0.001 ; n=33$ ) and directly proportional to total length for fishes in Dinh River (Fig. 9c). Only with the $R^{2}$ value (0.2046), the correlation in Suoi Trau Reservoir can be calculated $\left(\log \left(F_{t}\right)=4.527 \log \left(L_{t}\right)-17.583 ; t=2.683 ; p=0.012 ; n=30\right)(F i g .9 d)$.

\subsection{Oocyte diameter}

The diameter of the Top Decile oocytes at stage IV-V ovaries of the Pterygoplichthys spp. in Dinh river and Suoi Trau reservoir were $2.94 \pm 0.03 \mathrm{~mm}$ (ranged from 2.50 to $3.46 \mathrm{~mm}$ ) and $2.58 \pm 0.01 \mathrm{~mm}$ (ranged from 2.42 to $2.80 \mathrm{~mm}$ ), respectively. There was a significant difference in the mean diameter of the Top Decile oocytes among fish from lotic and limnic habitats (Table 4).

\section{Discussion}

We documented the first evidence on how suckermouth armored catfishes have evolved in phenotypic divergences when inhabit lotic and limnic habitats in Vietnam. Indeed, all growth and reproductive results indicate that Pterygoplichthys spp. in lotic had faster growth, higher fecundity, and longevity; these results were consistent for all sampling months throughout a year with a large number of specimens. Furthermore, these populations are within the same climate region, suggesting that they may experience the same climatic conditions (Table 1). The substantial phenotypic divergences of fish in lotic and limnic habitats may directly relate to hydrology, water flow (Table 1), food availability and predators. In the following paragraphs, we will discuss in details how Pterygoplichthys spp. have evolved in phenotypic divergences in growth and reproduction, which are critical for their invasion in lotic and limnic habitats in Vietnam.

Table 1

Parameters of sampling locations

\begin{tabular}{|lll|}
\hline Parameters & Dinh River & Suoi Trau Reservoir \\
\hline Geographic & $12^{\circ} 29.740^{\prime}$ & $12^{\circ} 30.302^{\prime}$ \\
\hline Coordinates $(\mathrm{N}, \mathrm{E})$ & $109^{\circ} 7.686^{\prime}$ & $109^{\circ} 2.694^{\prime}$ \\
\hline Type & lotic & limnic \\
\hline Length $(\mathrm{km})$ & 53 & - \\
\hline Square - Volume & $916 \mathrm{~km}^{2}$ & $(1.42-9.8) \times 10^{6} \mathrm{~m}^{3}$ \\
\hline Altitude $(\mathrm{m})$ & 2 & 22 \\
\hline Depth $(\mathrm{m})$ & $3-4$ & $4-9$ \\
\hline Water speed $(\mathrm{m} / \mathrm{s})$ & $0.1-0.7$ & 0 \\
\hline Temperature $\left({ }^{\circ} \mathrm{C}\right)$ & $25.4-32.9$ & $25.4-32.9$ \\
\hline pH & $6.75-7.58$ & $7.09-8.5$ \\
\hline Salinity $(\%)$ & $0.04-0.05$ & 0.0 \\
\hline TDS, ppm & $48-60$ & $71-100$ \\
\hline Total P $(\mu g / l)$ & $45.9-75.9$ & $49.7-65.3$ \\
\hline Total N $(\mu g / I)$ & $769-985$ & $826-869$ \\
\hline Atmospheric pressure $(\mathrm{mmHg})$ & $757-758$ & $760-761$ \\
\hline
\end{tabular}

Both males and females of Pterygoplichthys spp. collected from the Dinh River (lotic habitat) and Suoi Trau Reservoir (limnic habitats) in this study had negative allometric growth $(b=2.66-2.89)$, indicating that these fish were likely to be slimmer 
when they grow bigger. This finding was consistent with the growth pattern of $P$. pardalis from Langat river, Malaysia $(b=$ $2.538 \pm 0.039$ ) (Samat et al. 2008) and Pterygoplichthys spp. from six water bodies in Guangdong Province, China $(b=$ 2.515-2.973) (Wei et al. 2017).

Another important line of evidence for the strong phenotypic divergence in Pterygoplichthys spp. are the size, maximal size and age of both males and females of from Dinh River (lotic habitat) were about 45-50\% longer than those from Suoi Trau Reservoir (limnic habitat). Indeed, the maximum length and lifespan of Pterygoplichthys spp. from Dinh River were $50 \mathrm{~cm}$ and 4.2 years old, and those from Suoi Trau were $34.6 \mathrm{~cm}$ and 2.9 years old. The differences between the two types of water bodies (Table 1) may result in variation in food, dissolved oxygen, territory, or other interspecific competition and subsequently affect the size of the fish. In general, Pterrygoplicthys spp. have rapid growth (10 cm/year) and a relatively short lifespan (ca. 5 years) (Gibbs et al. 2013; Gibbs et al. 2017). The lifespan of Pterrygoplicthys spp. in both Dinh river and Suoi Trau Reservoir were less than the estimated lifetime of this species in Volusia Blue Spring, Florida, USA (5.25 years) (Gibbs et al. 2013, Gibbs et al. 2017) whereas they had a similar length ( $L_{\infty}=50-52 \mathrm{~cm}$ ). The shorter lifetime may relate to the higher average temperature in Vietnamese habitats than in Floridan habitats, as lifetime and temperature typically correlate negatively (Truong et al. 2020).

In this study, six stages of gonadal development of Pterygoplichthys caught from Dinh River and Suoi Trau Reservoir were described and similar to Jumawan and Herrera (2014). However, the weight of stage I gonad in Pterygoplichthys spp. in this study was 10-fold smaller than that of fish collected at Marikina river, Philippines (Jumawan and Herrera 2014), which may relate to the difference in size at maturity. Furthermore, this fish species can alter its reproductive strategies (either annual single spawner or annually repeated spawner) and its GSI index in adults varied greatly, which may explain the difference.

Interestingly, the size at 50\% maturity of females of Pterygoplichthys spp. in Suoi Trau Reservoir and Dinh River was $13 \mathrm{~cm}$ $\mathrm{L}_{\mathrm{s}}, 15.91 \mathrm{~cm} \mathrm{~L}$, respectively; which is much smaller than in their native habitats. In South America, the native Loricariids began to breed at a size of $25 \mathrm{~cm}$, unknown $\mathrm{L}_{s}$ or $\mathrm{L}_{t}$ (Mendoza 2009). In North America, the 50 percent sexual maturity of $P$. disjunctivus was $19.2 \mathrm{~cm} \mathrm{~L}_{\mathrm{s}}$ in El Infiernillo Reservoir, Mexico (Rueda-Jasso et al. 2013) and $26 \mathrm{~cm} \mathrm{L_{s }}$ in Volusia Blue Spring Florida, USA (Gibbs et al. 2008; Gibbs et al. 2017). In Asia, the 50 percent sexual maturity was $24 \mathrm{~cm} \mathrm{~L}_{t}$ of $P$. disjunctivus in East Kolkata Wetlands, Indian (Suresh et al. 2019) and Taiwan was $25 \mathrm{~cm} \mathrm{~L}_{s}$ of $P$. multiradiatus from Kaoping river (Liang et al. 2005), and was $26 \mathrm{~cm} \mathrm{~L}_{s}$ of $P$. disjunctivus in Marikina river, Philippines (Jumawan and Herrera 2014). In our study, the size at first maturation of fish is smaller than fish in native and other studies (similar to $P$. pardalis in Peninsular river, Malaysia, $13 \mathrm{~cm} \mathrm{~L}_{s}$, Samat et al. 2016). The smaller size at maturity may be a response to the exploitation pressure, removing the majority of large-size, matured animals from the populations (de Roos el al. 2006). This is unlikely the case for suckermouth armored catfishes as they are not the primary target for fish exploitation. More likely, the smaller size at maturation is one of the universal patterns of ectothermic animals in response to elevated temperature (Daufresne et al. 2009; Cheung et al. 2013); the development outpaces the growth when temperature increases until the upper thermal optimum (Forster et al. 2011). Corroborating to this, the average water temperature in both Dinh River and Suoi Trau Reservoir varies between $25.4-32.9^{\circ} \mathrm{C}$, higher than in Florida, U.S.A., around $23^{\circ} \mathrm{C}$ (Gibbs et al. 2017). The smaller size at maturity of Vietnamese animals in reponse to elevated temperature has been observed in aquatic invertebrates of the same location (Doan et al. 2019), but none have documented the evidence for fish in Vietnam.

In this study, Pterygoplichthys was found to breed all year round, as indicated by the monthly changes in GSI and the percentage of fish with matured stages. The main reproductive season would be from April to October, with a peak in JulyAugust as indicated by the highest GSI values of fish collected from both Dinh River and Suoi Trau Reservoir during this period. This finding was consistent with a previous study which reported that Pterygoplichthys in Dinh River was fertile from October to December (GSI: 6.59-15.77\%) and recovered in January (Zworykin and Budaev 2012). These results also agree with the observation of the main breeding season of Pterygoplichthys in the summer regardless of invading habitats worldwide. For example, in Mexico and the United States of America Pterygoplichthys reproduces in summer from May to October or November (Rueda-Jasso et al. 2013; Gibbs el al. 2008; Gibbs et al. 2017). P. multiradiatus in Kaoping River, 
Taiwan, breed from March to September with a peak from June to August (Liang et al. 2005). In other geographical areas with only two seasons (rainy and dry seasons), the main reproductive season of Pterygoplichthys occurs in the rainy season. For example, in Malaysia, the P. pardalis reproduce from September to January (Samat et al. 2016), the P. disjunctivus from June to September in The Philippines (Jumawan and Herrera 2014) and from July to November in India (Suresh et al. 2019).

P. disjunctivus could change their reproductive strategy to adapt to the local environment (Gibbs et al. 2017). The reproductive strategy of Pterygoplichthys spp. from southern Vietnam was diverse. Pterygoplichthys spp. can be the single spawner with only one time reproduction per year as indicated by the index $F_{b} / F_{t}=100 \%$ or multiple spawners which could reproduce several times a year as indicated by $F_{b} / F_{t}$ index varying from $7.9 \%$ to nearly $100 \%$ (Table 4 ). In India and The Philippines, P. disjunctivus are multiple spawners only (Suresh et al. 2019; Jumawan and Herrera 2014). The alteration in their reproductive strategies may be interpreted as an adaptation to variations in environmental, biological or geographical conditions (Gibbs et al. 2017), which need to be clarified in freshwater habitats in southern Vietnam.

One important finding of this study was that the absolute fecundity of Pterygoplichys spp. was five times higher in Dinh River than in Suoi Trau Reservoir, although the distance between the two sampling sites is only $8 \mathrm{~km}$, and with the same weather conditions. The difference in absolute fecundity of Pterygoplichys spp. was associated with the larger body size of fish collected from these two habitats, as confirmed by the positive correlations between these two parameters (Fig. 9). Indeed, the difference was no longer present when the fecundity was normalized for the body size as there was no significant difference in relative fecundity of Pterygoplichys spp. from lotic and limnic habitats. Furthermore, the type of water bodies or water quality parameters (Table 1) may also contribute to this difference. The relative fecundity of Pterygoplichys spp. in this study was comparable to P. disjunctivus from El Infiernillo Reservoir, Mexico $\left(\mathrm{RF}_{\mathrm{t}}=12.5 \mathrm{eggs} / \mathrm{g}\right)($ Rueda et al. 2013) and East Kolkata Wetlands, Indian $\left(\mathrm{RF}_{\mathrm{t}}=8-22 \mathrm{egg} / \mathrm{g}\right)$ (Suresh et al. 2019).

The average diameter of the top size class eggs in Pterygoplichys spp. from Dinh River was moderately larger ( 13\%) than that of fish from Suoi Trau Reservoir, which may relate to the adaptive responses to different habitat conditions. Generally, the smaller eggs size in reservoirs may result from unfavourable environmental conditions such as high water temperature variations, higher water level changes and fluctuations, food shortages accompanied by a long dry season. Indeed, the size of fish from Dinh River were larger than in Suoi Trau Reservoir (Table 3) and fish obtained from Dinh River had a higher abundance of food in the digestive tract (benthic, planktonic, amphibiontic, terrestrial food items) than in Suoi Trau Reservoir (only benthic, planktonic) (Stolbunov and Gusakov et al. 2021). This leads to the larger diameter of the top size class eggs in Dinh River than in Suoi Trau Reservoir. Other studies in lotic habitat such as: in Volusia Blue Spring, Florida, U.S.A (latitude $28^{\circ} \mathrm{N}$ ), average diameter top decile class size of period 2005-2007 was 3.44 mm, period 2012-2014 was $3.01 \mathrm{~mm}$ (Gibbs et al. 2008; Gibbs et al. 2017) and the diameter of the top size class eggs was 3-4 mm for fish from Marikina River, The Philippines (latitude $\sim 14^{\circ} \mathrm{N}$ ) (Jumawan and Herrera 2014) are larger than the top decile class size in Dinh River, Viet Nam (latitude $\sim 12^{\circ} \mathrm{N}$ ). It seems that, the size of the egg smaller toward the lower latitudes which needs further investigations.

Overall, the study results showed that the growth, lifespan, fecundity and egg diameter of suckermouth-amored catfishes in limnic showed smaller values than in the lotic habitat, suggesting a strong phenotypic diversgence. A generally short lifespan of Pterygoplichthys spp. together with the small size at 50\% maturation, high fecundity, being single and multiple spawners and ready to reproduce at any months of the years, all of these important characteristics suggest that Pterygoplichthys spp. are highly opportunistic to any local conditions and habitats in Vietnam where they invade. It is still unknown whether these phenotypic divergences have a genetic basis, which may be revealed by a common-garden experiment. Irrespective of the mechanisms, our results are the first and shed light on how Pterygoplichthys spp. are thriving in typical freshwater habitats in Vietnam.

\section{Conclusions}

This study provided important scientific base on the reproductive biology and growth of armored catfish in different water bodies in the south of Vietnam. The fish from two different water bodies significantly varied in the length of the fish, size of 
oocytes, fecundity, the total length at maturity and allometric growth pattern, but there was no difference in ratio between males and females and relative fecundity. Macroscopic observations and histological examinations of the gonad of these fish indicated that they could breed all year round with a peak from July to August.

\section{Declarations}

\section{Funding}

This study was carried out within the frameworks of Ecolan 3.2. "Taxonomic diversity, ecology and behavior of freshwater hydrobionts" and a State Assignment no. 121051100104-6. Tran Duc Dien was funded by Vingroup Joint Stock Company and supported by the Domestic Master/ PhD Scholarship Programme of Vingroup Innovation Foundation (VINIF), Vingroup Big Data Institute (VINBIGDATA), code VINIF.2020.TS.84.

\section{Acknowledgments}

The authors are grateful to Pavlov E.D., Gusakov V.A., Le Tran Thuy Duong, Dao Tuan Vu, co-workers in Vietnam - Russia Tropical Centre, local fishermen for contributing to sample collection and Vingroup Joint Stock Company. Thanks to Ninh Hoa and Khanh Hoa Hydrometeorological Agency for providing meteorological data in the study area and water bodies.

\section{Competing interests}

The authors have no conflicts of interest regarding this work

\section{Author contributions}

All author contributed to the study conception and design. Tran Duc Dien: Ideas, field work, data collection and analysis, first draft preparation and editing, and funding. Vo Thi Ha: Ideas, field work, data collection and analysis, and manuscript editing. Mai Dang: Ideas, data analysis, manuscript editing. Huynh Minh Sang: Ideas, data collection and analysis, and manuscript editing. Khuong V. Dinh: Ideas, data analysis, and manuscript editing. Nguyen Trinh Duc Hieu: Data analysis and manuscript editing. Stolbunov I.A.: Ideas, data analysis, manuscript editing and funding. All author read and approved the final manuscript.

\section{Data availability statements}

The datasets analyzed during this current study are available from the corresponding author on reasonable request.

\section{References}

1. Alfaro REM, Cudmore B, Orr R (2009) Trinational Risk Assessment Guidelines for Aquatic Alien Invasive Species: test Cases for the Snakeheads (Channidae) and Armored Catfish (Loricariidae) in North American Inland Waters, ISBN 978-2923358-60-4, pp1-100

2. Armbruster JW, Page LM (2006) Redescription of Pterygoplichthys puntatus and description of a new species of Pterygoplichthys (Siluriformes: Loricariidae). Neotropical Ichthyology 4(4):401-409. https://doi.org/10.1590/S167962252006000400003

3. Bijukumar A, Smrithy R, Sureshkumar U, George S (2015) Invasion of South American Suckermouth Armoured Catfishes Pterygoplichthys spp. (Loricariidae) in Kerala, India - a Case Study. Journal of Threatened Taxa 7(3):6987-6995

4. Burgiel S W, Muir AA (2010) Invasive species, climate change and ecosystem-based adaptation: addressing multiple drivers of global change. Global Invasive Species Programme. September 2010. 55 p. DOI:10.13140/2.1.1460.8161

5. Cheung WW, Sarmiento JL, Dunne J et al (2013) Shrinking of fishes exacerbates impacts of global ocean changes on marine ecosystems. Nature Climate Change 3(3): 254-258 
6. Daufresne M, Lengfellner K, Sommer U (2009) Global warming benefits the small in aquatic ecosystems. Proceedings of the National Academy of Sciences of the United States of America 106:12788-12793. doi:10.1073/pnas.0902080106

7. de Roos AM, Boukal DS, Persson L (2006) Evolutionary regime shifts in age and size at maturation of exploited fish stocks. Proceedings of the Royal Society B. 273:1873-1880. doi:10.1098/rspb.2006.3518

8. Dong X, Xiang T, Ju T et al (2019) Age, growth, mortality and recruitment of thin sharpbelly Toxabramis swinhonis Günther, 1873 in three shallow lakes along the middle and lower reaches of the Yangtze River basin, China. PeerJ 7:e6772 DOI 10.7717/peerj.6772

9. Duarte S, Araújo FG (2002) Fecundity of the Hypostomus affinis (Siluriformes, Loricariidae) in the Lajes Reservoir, Rio de Janeiro, Brazil. Revista de Biologia Tropical 50(1):193-197

10. Gayanilo F, Sparre P, Pauly D (2005) FAO-ICLARM stock assessment tools (FISAT-II) user's guide. Rome: Computerized Information Series, FAO. $163 \mathrm{p}$

11. Gibbs M, Watson P, Johnson-Sapp K, Lind C (2017) Reproduction revisited - a decade of changes in the reproductive strategies of an invasive catfish, Pterygoplichthys disjunctivus (Weber, 1991) in Volusia Blue Spring. Aquatic Invasions 12(2):225-239. https://doi.org/10.3391/ai.2017.12.2.10

12. Gibbs MA, Kurth BN, Bridges CD (2013) Age and growth of the loricariid catfish Pterygoplichthys disjunctivus in Volusia Blue Spring, Florida. Aquatic Invasions 8(2):207-218. http://dx.doi.org/10.3391/ai.2013.8.2.08

13. Gibbs MA, Shields JH, Lock DW, Talmadge KM, Farrell TM (2008) Reproduction in an invasive exotic catfish Pterygoplichthys disjunctivus in Volusia Blue Spring, Florida, USA. Journal of Fish Biology 73:1562-1572. DOI: 10.1111/j.1095-8649.2008.02031.x

14. Godwin JC, Steen DA, Werneke D, Armbruster JW (2016) Two significant records of exotic tropical freshwater fishes in Southern Alabama, Notes Southeast. Nat.15(4):57-60

15. Gusakov VA, Stolbunov IA, Tran DD (2018) Modern distribution of armored catfishes (Siluriformes: Loricariidae) in Central Vietnam. Inland Water Biololy 11 (2):179-183. DOI: 10.1134/s1995082918020050

16. Hossain MY, VadasJr RL, Ruiz-Carus R, Galib SM (2018) Amazon sailfin catfish Pterygoplichthys pardalis (Loricariidae) in bangladesh: A critical review of its invasive threat to native and endemic aquatic species. Fishes 3(14). doi: 10.3390/fishes3010014.

17. Hussan A, Sundaray JK, Mandal RN et al (2019) Invasion of non-indigenous suckermouth armoured catfish of the genus Pterygoplichthys (Loricariidae) in the East Kolkata Wetlands: Stakeholders' perception. Indian J. Fish 66(2):29-42. doi: 10.21077/ijf.2019.66.2.86267-05

18. Huynh MS, Ho SL (2018) Reproductive biology of blue tang fish (Paracanthurus hepatus Linnaeus, 1776) in Khanh Hoa seawater, Viet Nam. Indian Journal of Geo Marine Sciences 47(04):839 - 845

19. IPBES, 2019. The global assessment report on biodiversity and ecosystem services. Summary for policymakers. ISBN No: 978-3-947851-13-3. pp. 60

20. Jumawan JC, Herrera AA (2014) Ovary morphology and reproductive features of the female suckermouth sailfin catfish, Pterygoplichthys disjunctivus (Weber 1991) from Marikina River, Philippines. Asian Fisheries Science 27:75-89

21. King M (1995) Fisheries biology, assessment and management, Fishing New Books, A division of Blackwell Science Ltd, 54 University Street, Carlton Victoria 3053, Australia. 341 pp.

22. Koutrakis ET, Tsikliras AC (2003) Length-weight relationships of fishes from three northern Aegean estuarine systems (Greece). Journal of Applied Ichthyology 19(4):258-260

DOI 10.1046/j.1439-0426.2003.00456.x

23. Liang S H, Wu HP, Shieh BS (2005) Size structure, reproductive phenology, and sex ratio of an exotic armored catfish (Liposarcus multiradiatus) in the Kaoping River of southern Taiwan. Zoological Studies 44(2):252-259

24. McLeay LJ, Doubell MJ, Linnane AJ (2019) Spatial and temporal variations in female size at maturity of a Southern Rock Lobster (Jasus edwardsii) population: A likely response to climate change, PLoS ONE 14(11):1-28. doi: 
10.1371/journal.pone.0225144

25. Mendoza R, Luna S, Aguilera C (2015) Risk assessment of the ornamental fish trade in Mexico: analysis of freshwater species and effectiveness of the FISK (Fish Invasiveness Screening Kit). Biology Invasions 17(12):3491-3502. doi: 10.1007/s10530-015-0973-5

26. Nico LG, Loftus WF, Reid JP (2009) Interactions between non-native armored suckermouth catfish (Loricariidae: Pterygoplichthys) and native Florida manatee (Trichechus manatus latirostris) in artesian springs. Aquatic Invasions 4(3):511-519. doi: 10.3391/ai.2009.4.3.13

27. Nikolsky GV (1963) The ecology of fishes. Academic press, London, 352 pp

28. O'Brien CM (2012) Modelling and quantitative methods in fisheries, second edition by Malcolm Haddon. International Statistical Review 80(1):201-202 DOI 10.1111/j.1751-5823.2012.00179_26.x

29. Orfinger AB, Goodding DD (2018) The global invasion of the suckermouth armored catfish genus Pterygoplichthys (Siluriformes: Loricariidae): annotated list of species, distributional summary, and assessment of impacts, Zoological Studies 57:e7. DOI: 10.6620/ZS.2018.57-07

30. Pauly D (1983) Some simple methods for the the assessment of tropical fish stock. Rome: Food and Agriculture Organization of the United Nations. FAO Fisheries Technical Paper No. 234, $52 \mathrm{p}$

31. Pauly D, Munro J (1984) Once more on the comparison of growth in fish and invertebrates. Fishbyte, The WorldFish Centre 2(1):1-21

32. R Core Team (2017) R: A language and environment for statistical computing. Vienna: R Foundation for Statistical Computing. Available at https://www.R-project.org/

33. Reid AJ, Carlson AK, Creed IF et al (2019) Emerging threats and persistent conservation challenges for freshwater biodiversity. Biolological Reviews 94:849-873. doi: 10.1111/brv.12480

34. Ricker WE (1975) Computation and interpretation of biological statistics of fish populations. Bulletin of the Fisheries Research Board of Canada 191:401

35. Rueda-Jasso RA, Campos-Mendoza A, Arreguín-Sánchez F et al. (2013) The biological and reproductive parameters of the invasive armored catfish Pterygoplichthys disjunctivus from Adolfo López Mateos El Infiernillo Reservoir, MichoacánGuerrero, Mexico. Revista Mexicana de Biodiversidad 84(1):318-326. doi: 10.7550/rmb.26091

36. Samat A, Shukor MN, Mazlan AG, Arshad A, Fatimah MY (2008) Length-weight Relationship and Condition Factor of Pterygoplichthys pardalis (Pisces: Loricariidae) in Malaysia Peninsula. Research Journal of Fisheries and Hydrobiology 3(2):48-53

37. Samat A, Yusoff FM, Arshad A et al. (2016) Reproductive biology of the introduced sailfin catfish Pterygoplichthys pardalis (Pisces: Loricariidae) in peninsular Malaysia. Indian Journal of Fisheries 63(1):35-41. https://doi.org/10.21077/ijf.2016.63.1.44937-05

38. Schofield PJ, Loftus WF (2014) Non-native fishes in Florida freshwaters: a literature review and synthesis. Reviews in Fish Biology and Fisheries 25(1):117-145. doi: 10.1007/s11160-014-9373-7

39. Sparre P, Venema S (1998) Introduction to tropical fish stock assessment. Rome: Food and Agriculture Organization of the United Nations. FAO FISHERIES TECHNICAL PAPER 306/1, Rev.2, ISSN 0429-9345, 407 p

40. Stolbunov IA, Gusakov VA, Tran DD, Nguyen THT (2021) Food Spectrum, Trophic and Length-Weight Characteristics of Nonindigenous Suckermouth Armored Catfishes Pterygoplichthys spp. (Loricariidae) in Vietnam. Inland Water Biology 14 (5): 597-605. DOI: 10.1134/S1995082921050163

41. Stolbunov IA, Tran DD (2019) Mass alien fish species in the fish fauna of inland waters in Central Vietnam. Inland Water Biology 12(4):477-480. DOI: 10.1134/S1995082919040163

42. Stolbunov IA, Tran DD, Armbruster JW (2020) Suckermouth-armored catfish (Siluriformes: Loricariidae) of Central and Southern Vietnam. Inland Water Biology 13(4):626-639. DOI: 10.1134/S1995082920040100 
43. Stolbunov IA, Tran DD, Karabanov DP (2021) Taxonomic composition and distribution of non-indigenous suckermouth amored catfishes (Siluriformes: Loricariidae) in South Vietnam. Inland Water Biology 14(3):263-273. DOI:

$10.1134 /$ S1995082921030123

44. Suresh VR, Ekka A, Biswas DK et al. (2019) Vermiculated sailfin catfish, Pterygoplichthys disjunctivus (Actinopterygii: Siluriformes: Loricariidae): Invasion, biology, and initial impacts in east Kolkata Wetlands, India. Acta Ichthyologica Et Piscatoria 49(3):221-233. doi: 10.3750/AIEP/02551

45. Torchin ME, Mitchell CE (2004) Parasites, pathogens, and invasions by plants and animals. Front Ecol Environ 2(4):183190. doi: 10.1890/1540-9295(2004)002[0183:PPAIBP]2.0.C0;2

46. Truong KN, Vu NA, Doan NX et al. (2020) Predator cues increase negative effects of a simulated marine heatwave on tropical zooplankton. Journal of Experimental Marine Biology and Ecology 530-531, 151415.

DOI:10.1016/j.jembe.2020.151415

47. von Bertalanffy L (1938) A quantitative theory of organic growth (inquiries on growth laws 11). Human Biology 10(2):181-213

48. Wei H, Copp GH, Vilizzi L et al (2017) The distribution, establishment and life-history traits of non-native sailfin catfishes Pterygoplichthys spp. In the Guangdong province of China. Aquatic Invasions 12(2):241-249. DOI:

https://doi.org/10.3391/ai.2017.12.2.11

49. Wu LW, Liu CC, Lin SM (2011) Identification of exotic sailfin catfish species (Pterygoplichthys, Loricariidae) in Taiwan based on morphology and mtDNA sequences. Zoological Studies 50(2):235-246

50. Ye S, Li Z, Feng G, Cao W (2007) Length-weight relationships for thirty fish species in Lake Niushan, a shallow macrophytic Yangtze Lake in China. Asian Fisheries Science 20:217-226. https://doi.org/10.33997/j.afs.2007.20.2.007

51. Zworykin DD, Budaev SV (2013) Non-indigenous armoured catfish in Vietnam: invasion and systematics. Ichthyol Res 60(4):327-333. DOI: 10.1007/s10228-013-0356-9

\section{Figures}
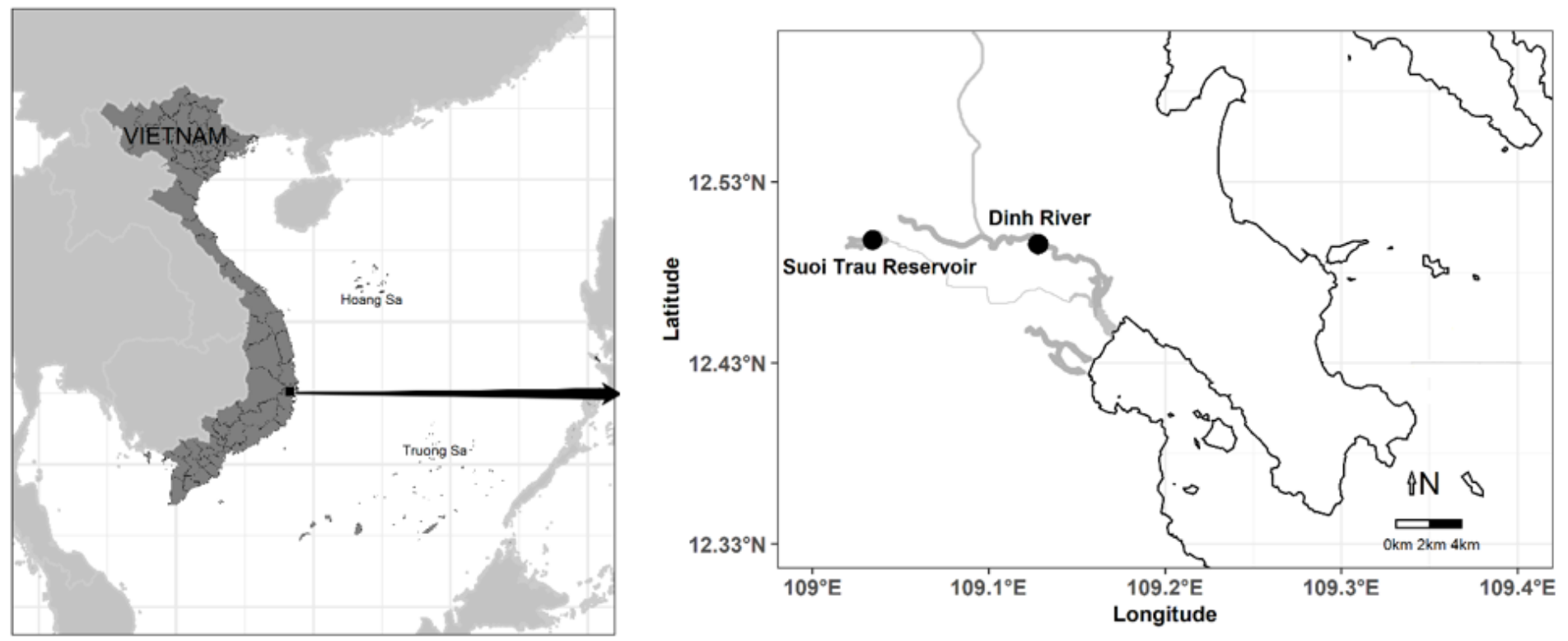

\section{Figure 1}

Map of sampling stations 


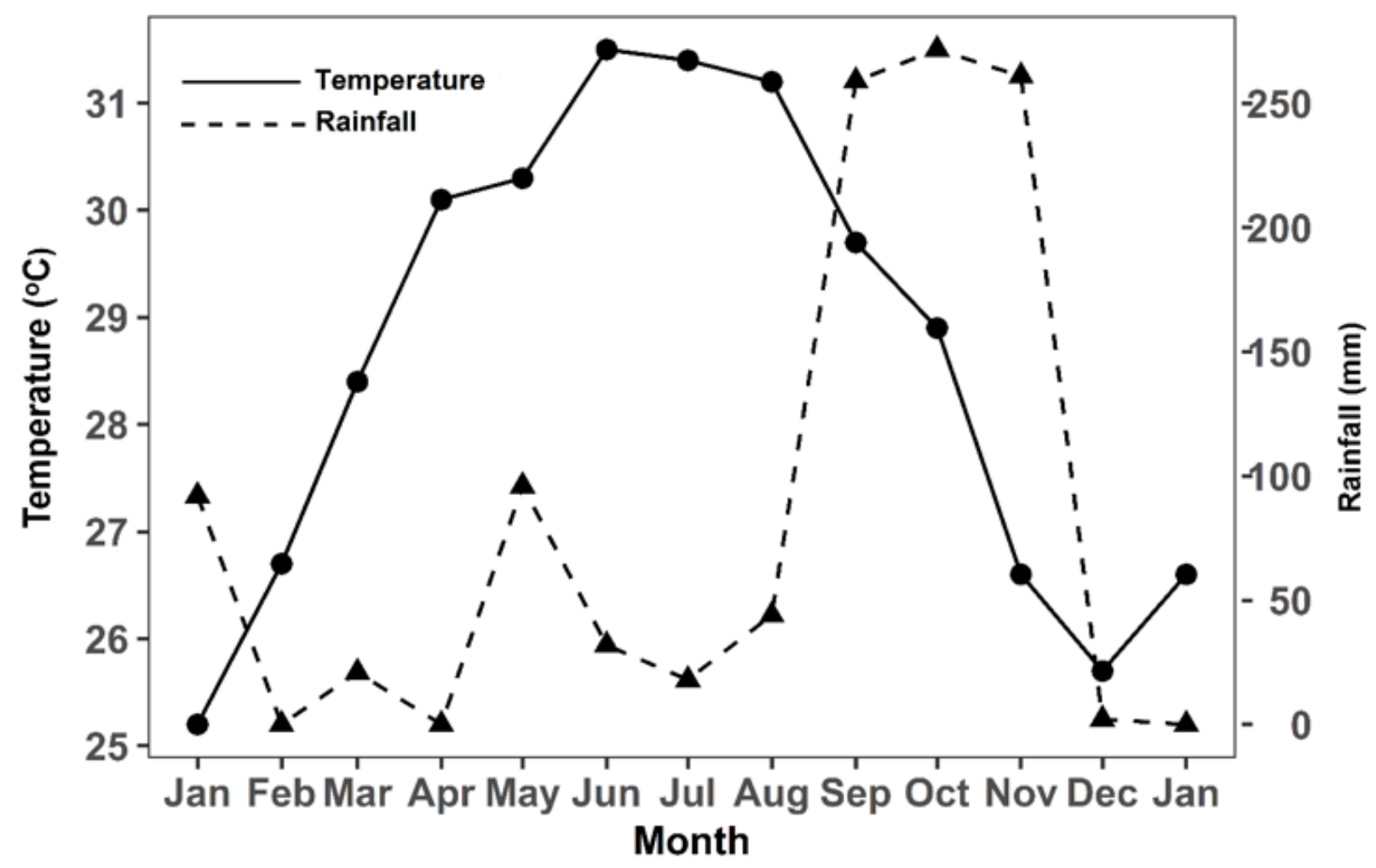

Figure 2

Air temperatute and rainfall in Ninh Hoa province includes Dinh River and Suoitrau Reservoir 

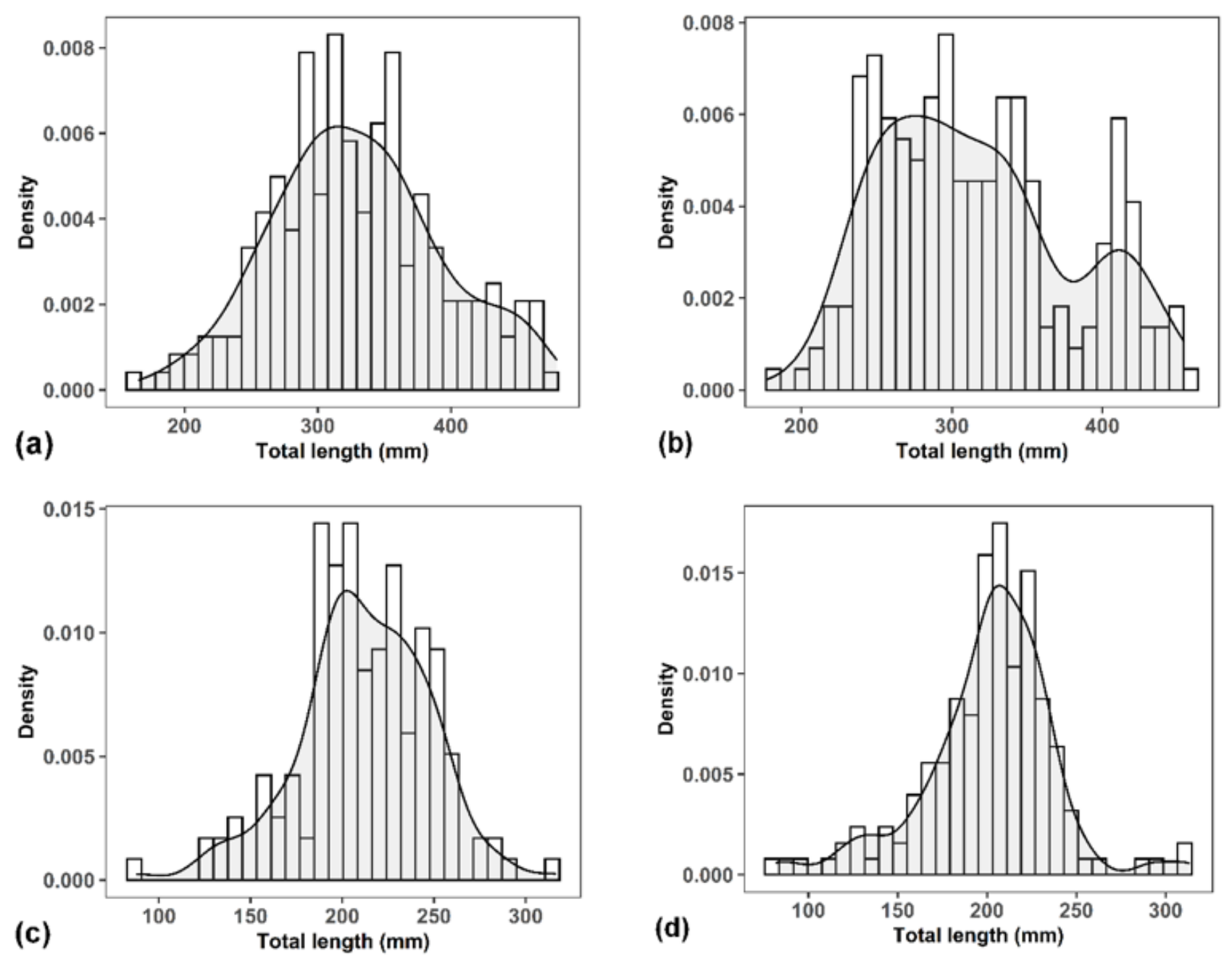

Figure 3

Total length frequency distribution of males and females of Pterygoplichthys spp. in Dinh River and Suoi Trau Reservoir: a Males in Dinh River; b - Females in Dinh River; c - Males in Suoi Trau Reservoir; d - Females in Suoi Trau Reservoir 


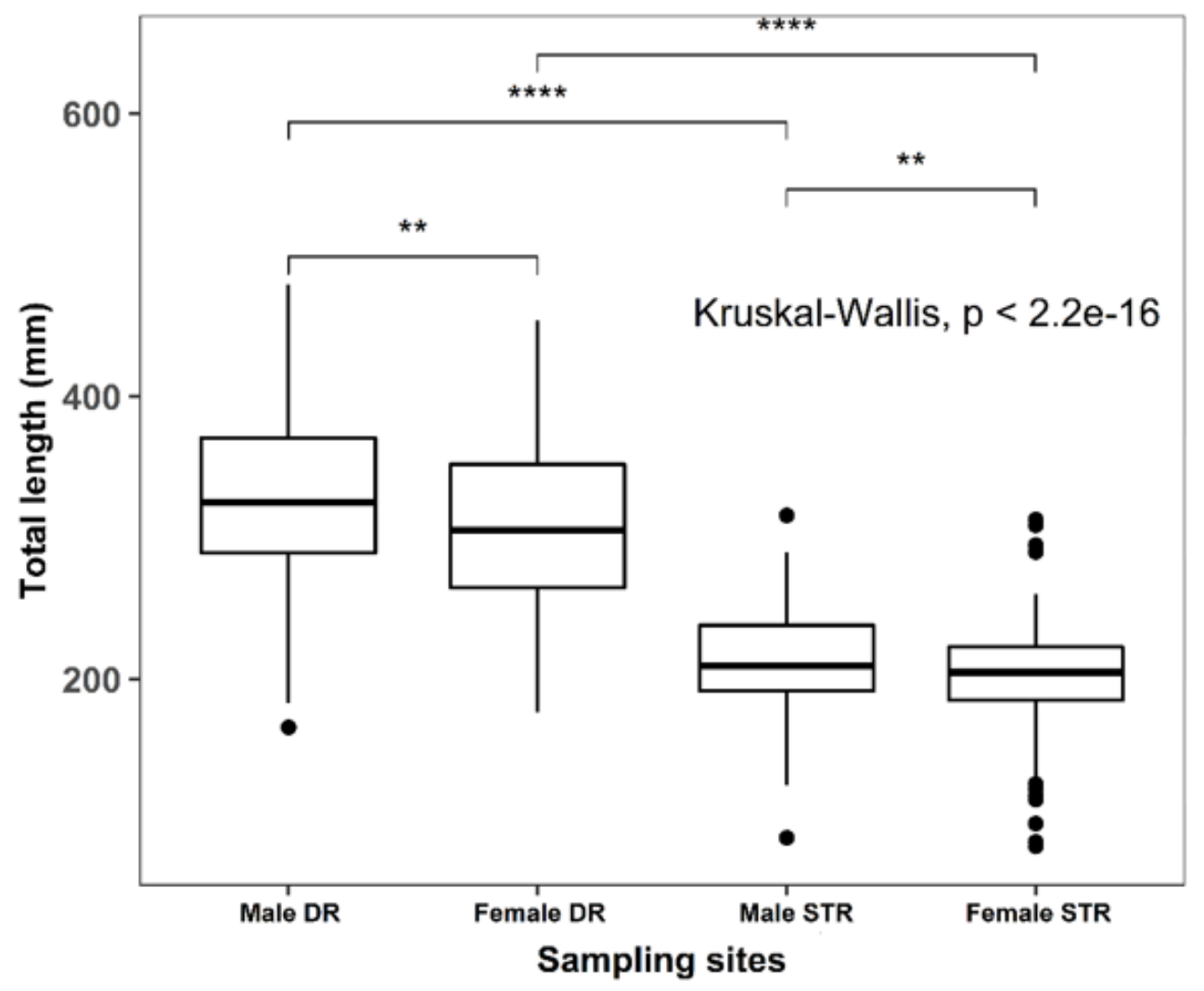

Figure 4

Boxplot (horizontal line within box: median, boundaries of the box: first and third quartiles, bars: lower and upper inner fences; outliers) about Kruskal - Wallis test in the total length $\left(L_{t}\right)$ of sexual Pterygoplichthys spp. in Dinh River-DR and Suoi Trau Reservoir-STR (**: $p<0.01 ; * \star *: p<0,001)$ 

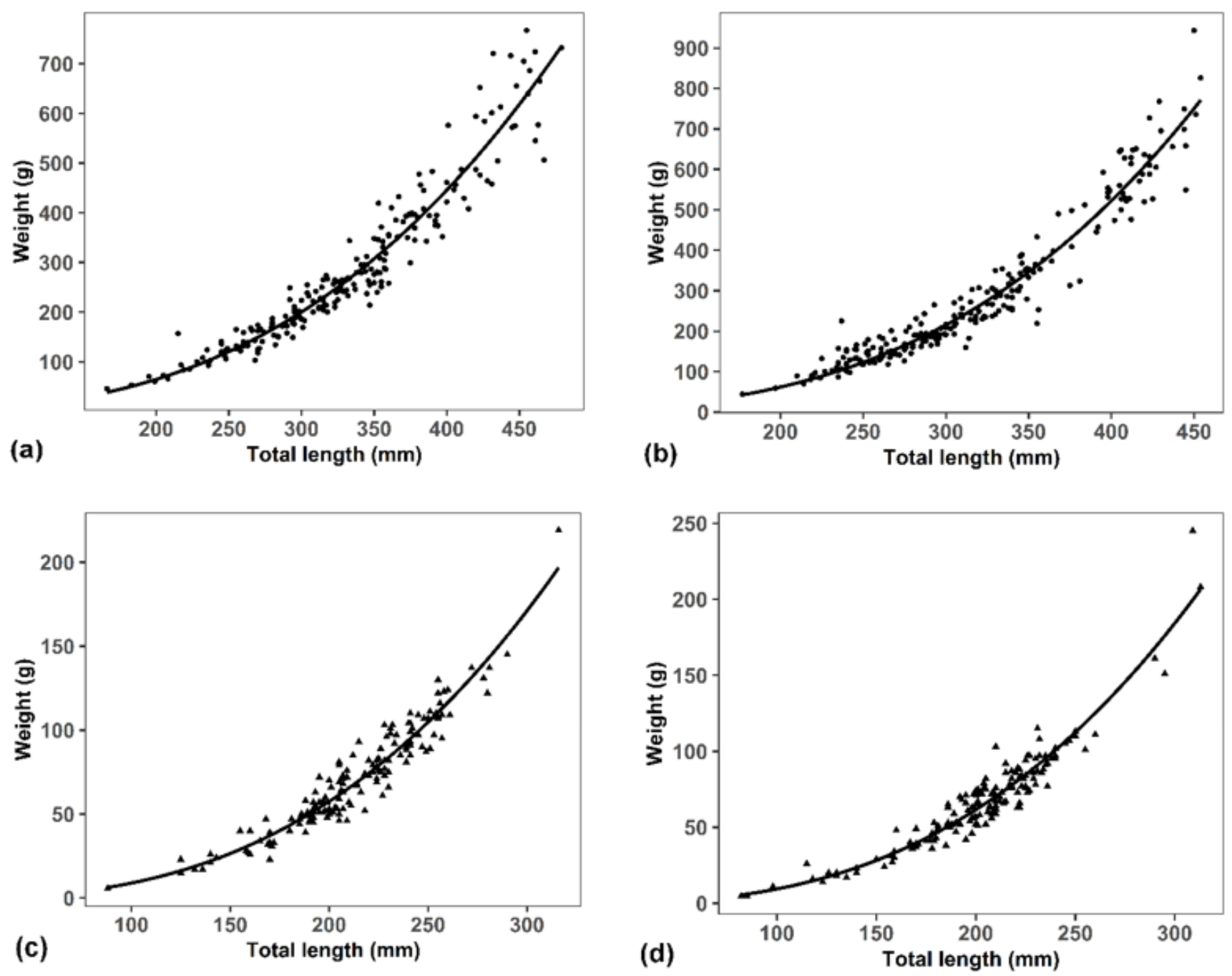

Figure 5

Total length-weight relationship of males and females of Pterygoplichthys spp. in Dinh River and Suoi Trau Reservoir: a Males in Dinh River; b - Females in Dinh River; c - Males in Suoi Trau Reservoir; d - Females in Suoi Trau Reservoir 

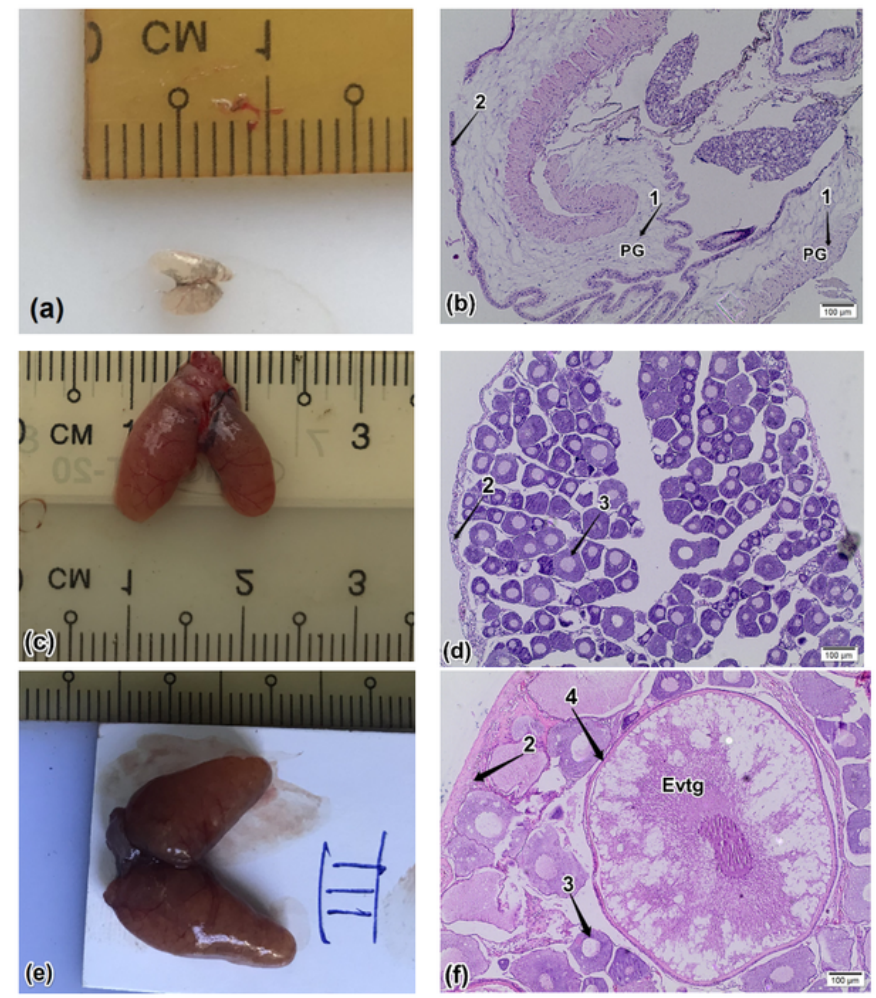

(e)
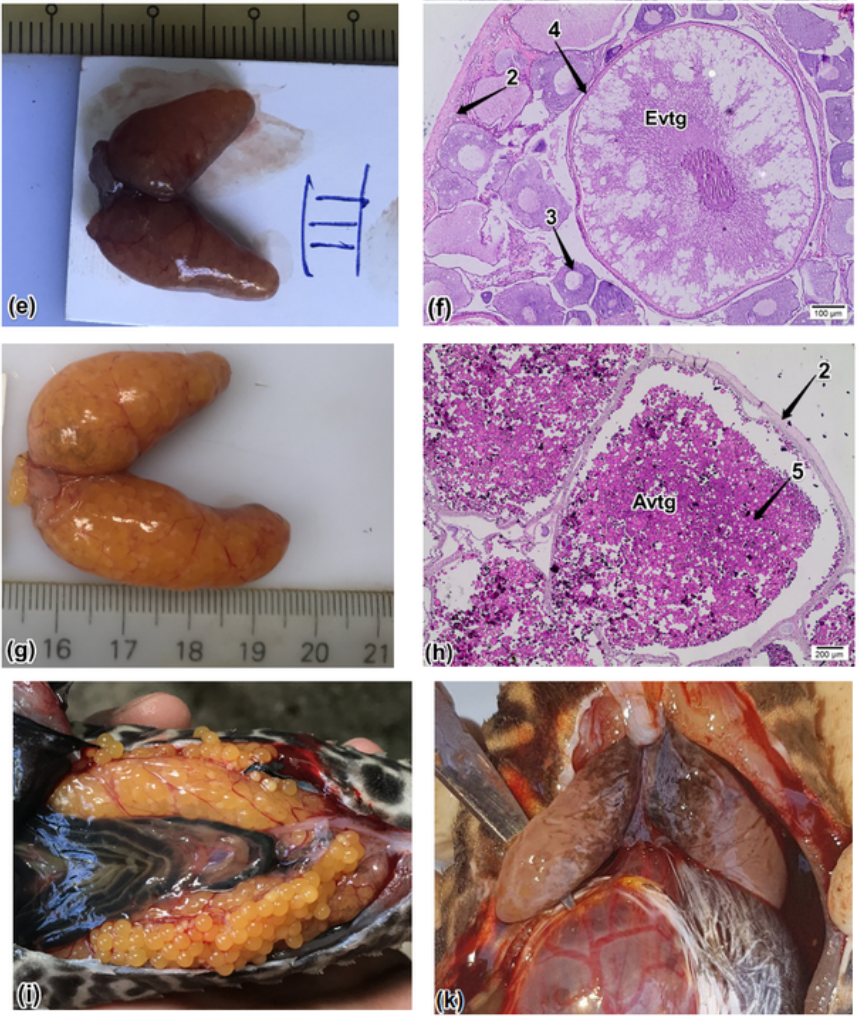

\section{Figure 6}

Macroscopic and and microscopic appearance the ovaries of the female Pterygoplichthys spp. at various maturity stages.

Note: a, b: stage l; c, d: stage II; e, f: stage III; $g$, h: stage IV; i: stage V and k: stage Vl; Evtg: early vitellogenic oocyte; Avtg: advanced vitellogenic oocyte; arrow 1-PG: primary growth oocyte; arrow 2 - Ovarian wall; arrow 3 - oocyte during previtellogenesis; arrow 4 -oocyte during vitellogenesis; arrow 5 -yolk granules in advanced vitellogenic oocyte 

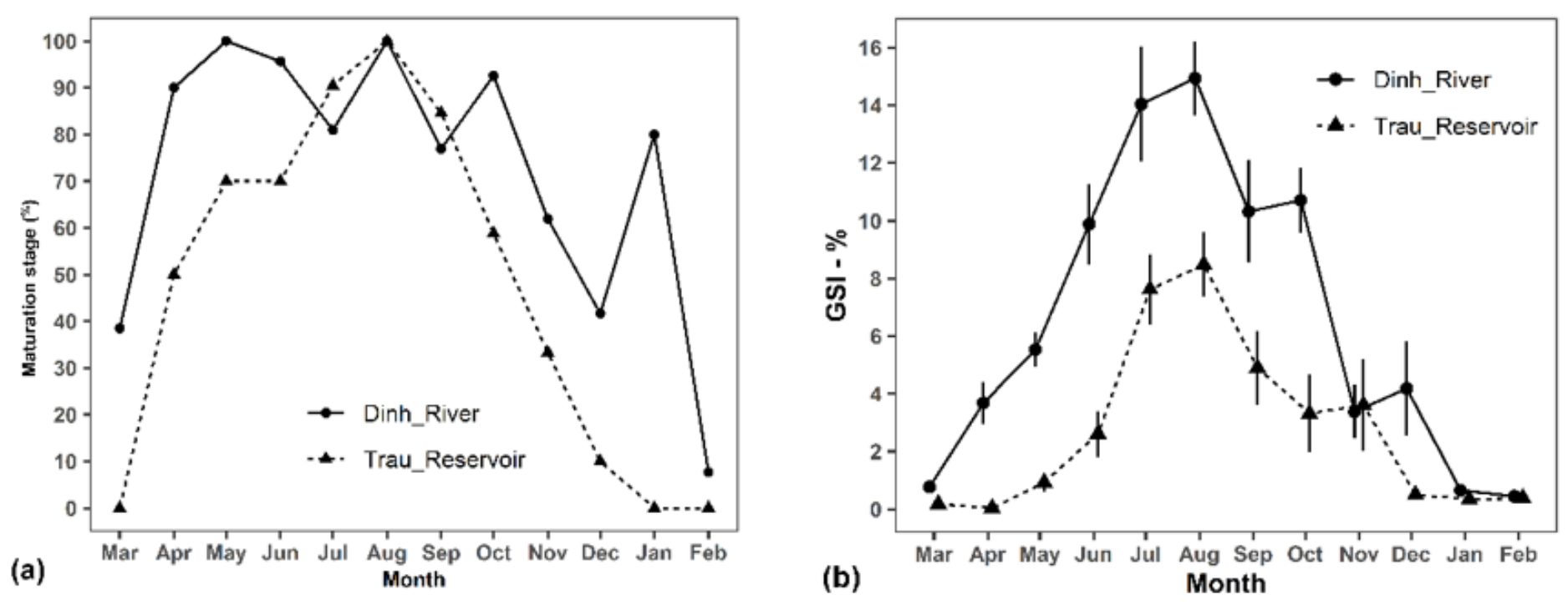

Figure 7

Monthly percentages of maturation stage (III-V) and monthly changes of the Gonado-somatic index (GSI) of the Pterygoplichthys spp.
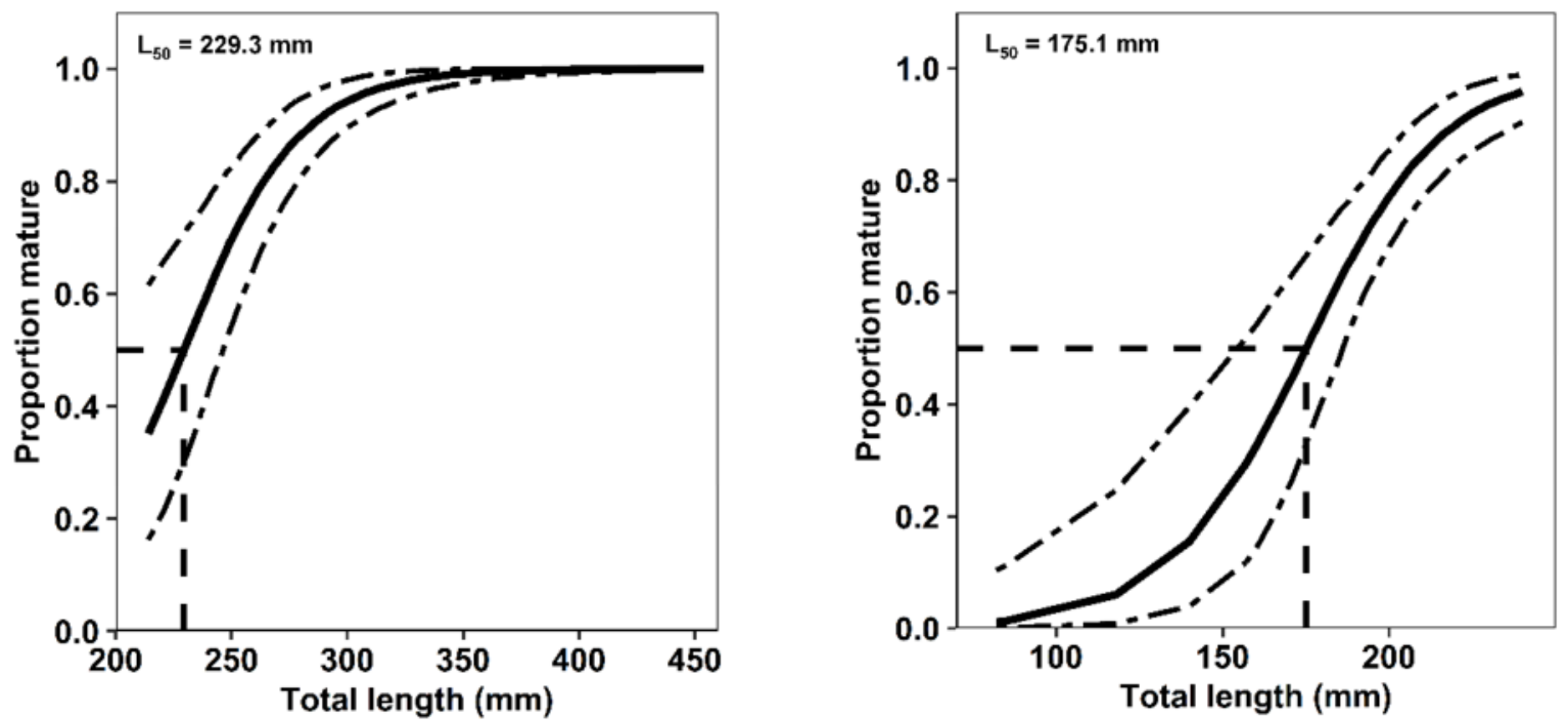

Figure 8

Length at the first sexual maturity $50 \%\left(L_{50}\right)$ of the Pterygoplichthys spp.: (a) - Dinh River, (b) - Suoi Trau Reservoir. 


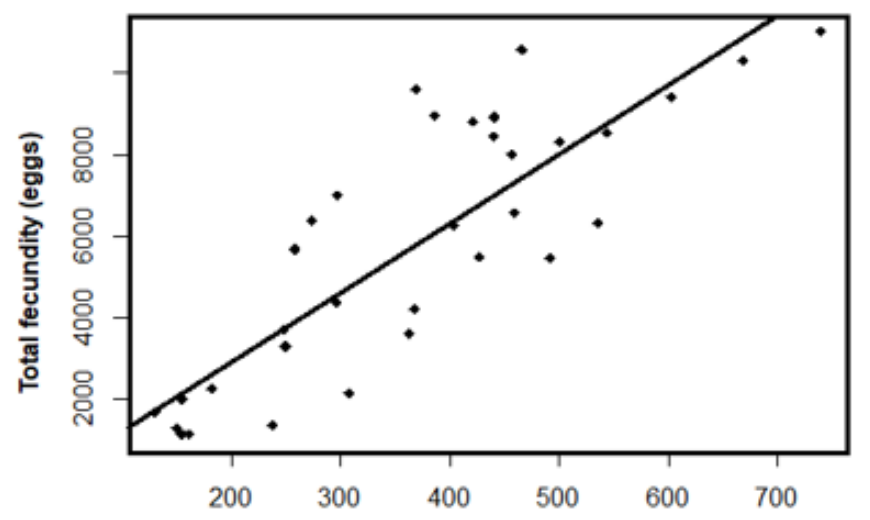

(a)

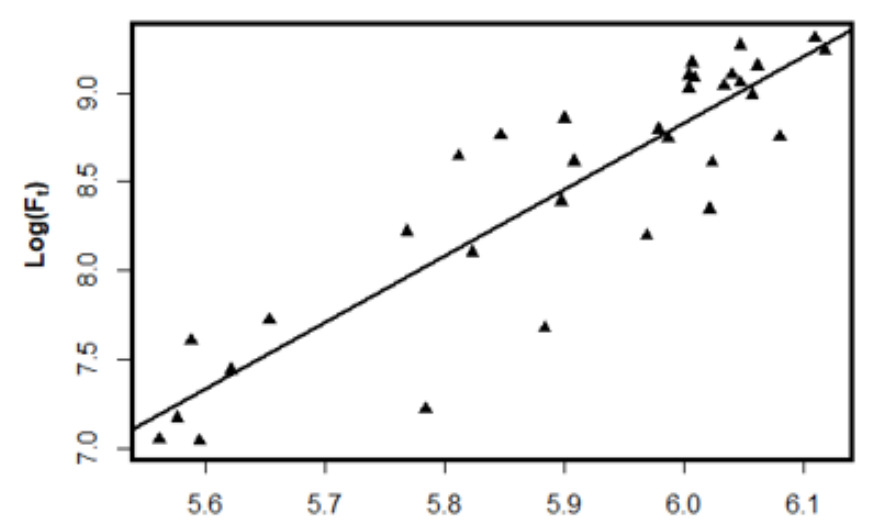

(c)

$\log \left(L_{t}\right)$

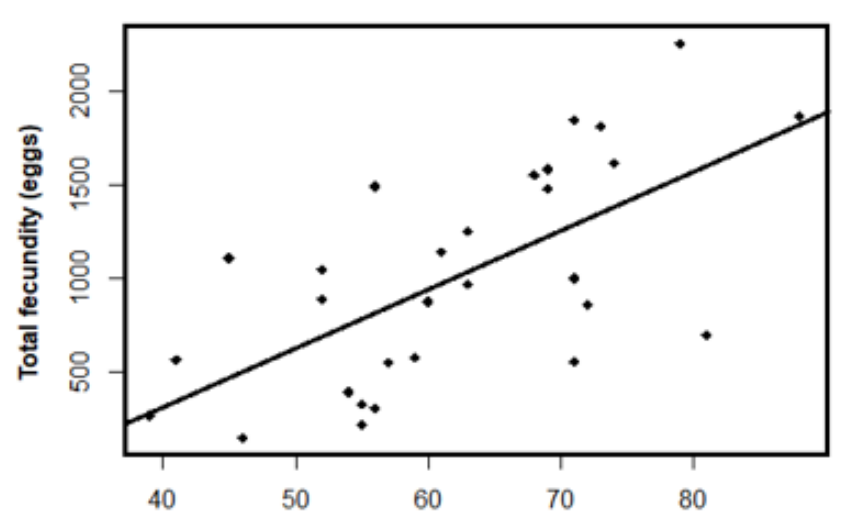

(b)

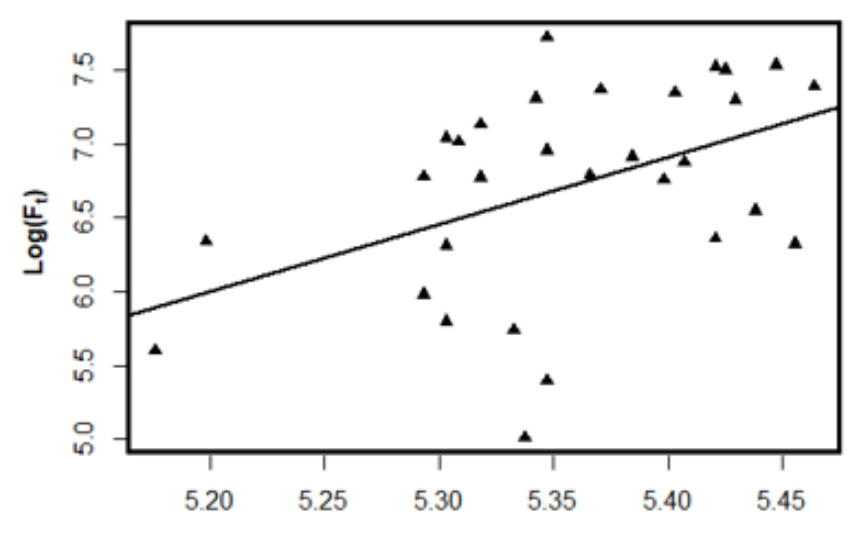

(d)

$\log \left(L_{t}\right)$

Figure 9

Correlation between total fecundity $\left(F_{t}\right.$, eggs) and total weight $\left(W_{t}, g\right)$, the red line indicates a $95 \%$ confidence interval: (a) Dinh River; (b) - Suoi Trau Reservoir. And correlation between total fecundity - $\log \left(F_{t}\right)$ and total length - $\log \left(L_{t}\right)$ : $(c)-\operatorname{Dinh}$ River; (d) - Suoi Trau Reservoir 